\title{
FACTORS INFLUENCING THE TOURISM COMPETITIVENESS OF FORMER SOCIALIST COUNTRIES
}

\author{
Zsófia Papp*, Ágnes Raffay \\ University of Pannonia, Faculty of Economics, Tourism Department, Veszprém, Hungary
}

\begin{abstract}
Tourism in the former socialist countries can be best characterised as a rollercoaster ride since the regime change around 1989-1990. After the changes they lost their appeal for the 'Western' tourists and also a large share of visitors from the socialist countries as it became possible to travel to countries beyond the 'friendly' countries. The social tourism schemes operating in these countries have been abandoned or changed. The EU accession has helped to revive tourism and roughly at the same time the introduction of low cost airlines opened new markets for the former socialist countries. The introduction of the Euro has impacted on the tourism of some of these countries as they have temporarily become cheaper or more expensive than other (neighbouring) countries. This paper will focus on the factors that have had an impact on the competitiveness of Hungary, Poland, Bulgaria and Romania.
\end{abstract}

Key words: Destination competitiveness, Competitive potential, Competitive position, Influencing factors.

\section{Introduction}

Since the overthrow of the old socialist regimes in the Central Eastern European countries fundamental political and economic changes have taken place. The new and freely elected governments faced the challenge of moving from central planning to market economies, and the transition took several years in each affected country, although the speed of gaining political stability and the state of the inherited economy affected the length of these transitional periods.

The political and economic changes also had significant impacts on tourism in the former socialist countries. The volume and nature of domestic tourism has changed, and international tourist arrivals have also been affected by the political and economic shifts as well as the social processes that had taken place since the changes started in 1989. On the one hand, the winding down and partial disappearance of social tourism made the restructuring of the tourism offer of the former socialist countries necessary in order to be able to appeal to emerging new markets. On the other hand, new destinations have opened up for the residents of the Central and Eastern European countries therefore the previously hardly known and recognised

${ }^{*}$ Corresponding author:

Email: papp@turizmus.uni-pannon.hu phenomenon of competition between destinations has emerged and started to demand attention in tourism management and development in the former socialist countries (Clarke, 2010).

The current paper will discuss the characteristics of tourism before the regime changes as well as the experiences of the changing demands and supply of tourism in the past two decades in four selected former socialist countries, Poland, Hungary, Romania and Bulgaria. The choice of countries was based partly on the interest of the authors and partly on the characteristics of the countries (Poland and Hungary with their more central location, closer to western borders and Romania and Bulgaria with their more southern locations and Mediterranean style seasides), and partly by the different phases of EU accession (Poland and Hungary joined the EU in 2004 and Romania and Bulgaria in 2007). The paper will also discuss theories of regional competitiveness and assess how the factors of competitive potential have changed in the past 20 years in these four countries.

\section{Characteristics of tourism of the former socialist countries}

One of the outstanding features of tourism in the former socialist countries before the political changes of 1989-1990 was strong domestic tourism. People were not only strongly encouraged to travel within 
their own country but were also provided the opportunity to do so. Most companies (which were obviously state owned in the socialist era) had their own holiday resorts by the sea or lakes or at spa resorts where their employees could enjoy a week's holiday with their families at affordable prices. Furthermore, trade unions also arranged affordable holidays for their members (although voluntary membership was just a token gesture, employees were strongly recommended to be a member of the respective unions of their profession). Youth camps and educational trips for children were organised so that the younger generations could also participate in tourism (Light and Dumbraveanu, 1999). The tourism infrastructure was of mixed quality, high quality hotels used primarily by party leaders and highly ranked officials as well as rather basic accommodation used by the workers of factories could be found in all of the four countries examined.

Two thoughts need highlighting from the strong social tourism of these countries. First, until the political (and economic) changes of 1989 the state was the provider of tourism infrastructure while in the Western countries the state gradually withdrew from being a provider of the tourism supply and focused more on the role of regulator and/or legislator of the tourism industry. Second, the state, through the companies and unions, provided holidays for the citizens but very often did not give them a choice of where to spend that holiday, therefore competition between places was virtually non-existent.

Although domestic tourism was the preferred and recommended choice, the citizens of the former socialist countries were also allowed to travel to the 'friendly' countries of the Council for Mutual Economic Assistance. In Romania for example up to $95 \%$ of the foreign tourist arrivals were realised by the citizens of the Central and Eastern European socialist countries (Hall, 1991). Travel outside the socialist countries was not encouraged, there were serious visa and foreign currency restrictions in place, people needed to have letters of invitation to be allowed to travel to a non-socialist country, and even so the number of such trips was limited over certain periods, and only a limited amount of currency could be exchanged which would hardly cover the expenses in the visited country.

With the overthrow of the old regimes political and economic restructuring became necessary. The old habit of planning centrally from a desk in an office had to be changed to a market driven economy where the needs and demands of potential customers as well as the competition had to be taken into account. The restructuring was a rather slow and painful process and has affected every area of economics as well as life. In the first 5-6 years after the change, the economic decline and the price liberalisation resulted in increased prices of commodities and services as well as inflation therefore people had less discretionary income to travel (Light and Dumbraveanu, 1999), while the state provided social tourism (in some cases only temporarily) collapsed.

However, for those who could still afford to travel new horizons opened up with the disappearance of the borders. Countries on the other side of the Iron Curtain became accessible, and in some cases also become cheaper than a holiday at a domestic destination. According to Wingrove (1997) for Romanian citizens a holiday in Greece was more affordable than by the Black Sea. However, the preference of new destinations in Western countries (especiallywithin driving distance) over the traditional Eastern European ones was most noticeable in the case of Polish and Hungarian tourism (Light and Dumbraveanu, 1999).

At the same time as citizens of former socialist countries were discovering new destinations outside the former socialist countries, these countries have started to lose their appeal to Western tourists. It was rather noticeable in Hungary for example which used to be a convenient meeting place for East and West German families (as East Germans could not travel to West Germany), where according to the Central Statistical Office of Hungary, the number of German tourists travelling to Hungary dropped from 5,185,666 in 1990 to $4,261,771$ by 1995 and to $3,317,406$ by 2005 (KSH, 1990, 1995, 2005; itthon.hu). In the case of Romania and Bulgaria this loss of foreign tourist arrivals was less noticeable as because of the longer distance and relatively poor transport infrastructure these countries received less foreign tourists. In Poland and Hungary however, partly because of the more central location and partly because of the perceived political stability and safety (compared to Romania for example), the tourism industry was more dependent on the international travellers. With the disappearance of the Iron Curtain these countries have become less interesting, less of a challenge as the distinctive character, the socialist/communist attitude and regime have gone. Until the EU accession a fluctuation could be observed in the number of tourist arrivals. The accession to the EU has given a new impetus to tourism in the former socialist countries as it opened new markets and development in the transport infrastructure making some of these countries more easily accessible. As an example, the introduction of low cost airlines often coincided with the date of the EU accession in the case of the four countries. Cheap flights have again made these countries not only accessible but also affordable. 


\section{Theories about destination competitiveness}

In the last two decades destination competitiveness has emerged as a major focus of tourism research. It started with the adoption of Porter's seminal work (1990) The Competitive Advantage of Nations and now there are several theories about the competitiveness of various territories. Several reports and articles have been published on the competitiveness of whole countries - just to mention the most popular competitiveness index from World Economic Forum (Blanke and Chiesa, 2009; Gomezelj and Mihalic, 2008) while in the field of regional economics the focus has been on smaller entities such as regions and cities (Heath, 2002; Cracolici and Nijkamp, 2008). In tourism the most appropriate kind of territory for deeper investigation is the destination - as the competition in tourism has intensified between destinations (Jancsik and Mayer, 2010).

The tourism destination as a place is hard to outline (as its borders depend more on the visiting tourists) and is hard to define. For one tourist a whole country can be a destination, while for another even a little village can be attractive enough to set off on a journey. For technical reasons many researchers (Gomezelj and Mihalic, 2008; Dwyer and Kim, 2003; Croes, 2011; Blanke and Chiesa, 2009) choose whole countries as tourist destinations, as they are easier to outline - and also much of the data and figures are more readily available at this level. For the purposes of this paper countries will be analysed as the regime changes that influence the differences between socialist and post socialist tourism are most often demonstrated at country level.

The importance of being competitive is not the subject matter anymore. This must be the main goal for both the successful and the less visited countries. The exact meaning of this phrase has been to some extent clarified due to Ritchie and Crouch's valuable contribution (2003) to the topic, although this is not based at the country level. The most accepted definition from the authors suggests that a destination is truly competitive if it has "ability to increase tourism expenditure, to increasingly attract visitors while providing them with satisfying, memorable experiences, and to do so in a profitable way, while enhancing the well-being of destination residents and preserving the natural capital of the destinations for future generations" (Ritchie and Crouch, 2003:2). This definition shows well that competitiveness is a complex term - which becomes really clear when we try to quantify, that is to measure the competitiveness of a destination.

But for effective tourism management it is essential for the destination to be able to measure its successes at any time and to be able to determine the points (factors) where certain management interventions (marketing, development, etc.) can help to achieve or maintain this success.

For this reason several theories have recently been developed about destination competitiveness, aiming to identify which factors can contribute to the success of a tourist destination and focusing on building up models based on those factors.

\section{Models and methods for research}

Some model developing authors aim to provide a framework for all influencing factors, like the most quoted Ritchie and Crouch (2003) or Heath (2002). Other researchers, such as Dwyer et al (2004), stand on the other side, focussing on one single aspect like the price-competition among destinations for example - besides their own general model.

The current paper does not allow for a long elaboration of all the efforts and models worked out so far. Therefore, the two most often quoted ones have been chosen to highlight the main directions and notions: the model of Ritchie and Crouch (2003) and Dwyer et al (2004).

The model of Ritchie and Crouch (2003) is held to be the most detailed and comprehensive work in tourism competitiveness - and it is also the starting point for many researchers to develop and process their own model. Ritchie and Crouch tried to collect and organise all the factors and determinants that the competitiveness of a destination is dependent on. Building on Porter's well-known framework (1990) of the diamond of national competitiveness, they organised 36 determinants into 5 components:

- supporting factors and resources,

- core resources and attractors,

- destination management,

- destination policy, planning and development,

- qualifying and amplifying determinants.

The basic component consists of the core resources and attractors that include the primary elements of destination appeal. Originally all the determinants have equal weight in the model, which is still the subject of discussions. To find the importance of the determinants Crouch (2011) has carried out research finding out the ranking of all the 36 determinants.

The model is also often criticised because it cannot show the connections or interference among the elements and therefore does not show a realistic picture (Armenki et al, 2011) - mainly compared to the model of Dwyer et al (2003).Figure 2.shows the model of Dwyer et al. 2004 . 


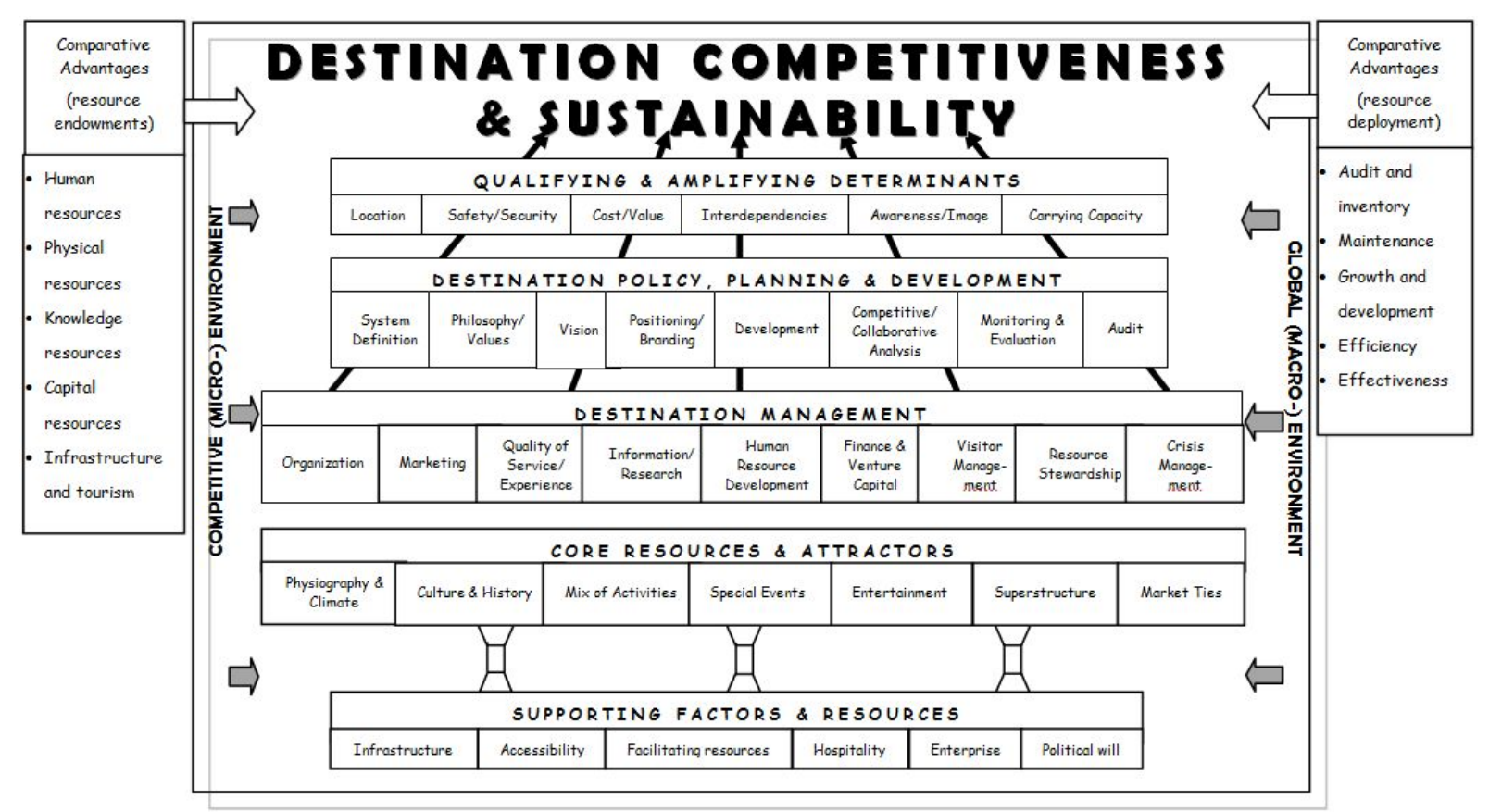

Figure 1. Destination Competitiveness Model of Ritchie-Crouch Source: Ritchie-Crouch, 2003

The so-called Integrated model presented by Dwyer et al (2004) has a lot of the elements of the Ritchie and Crouch model and also builds also upon Porter's framework as it brings together the main elements of national and corporate competitiveness into one overall model (Dwyer et al 2011). The two main elements of this model are the Resources and Destination Management. The first one is the base to attract visitors, but the second element is the one that can shape the basis for an attractive offer for tourists -to a competitive supply at the end. In addition the model groups two more determinants: Situational Conditions and Demand Conditions. The model is like a process that has two outcomes: destination competitiveness and socio-economic prosperity - which can be given by indicators of life quality (see Figure 2.). As the main goals are competitiveness and the good quality of life the model matches to the mentioned general (by Ritchie and (rouch) definition of competitiveness.

The model has a very important difference from Ritchie and Crouch: it shows causal links (Vanhove, 2010). The arrows in the model have special meaning: single direction arrows show the process, while twoway arrows stand for the mutual effects.

Both models are successful at identifying the factors influencing tourism destination competitiveness - but do not separate the factors. We would argue that there is a cause and effect logic between certain factors: some factors explain the competitive position of the destination and others relate to the potential of destination. The models lack this logic and mix the factors from both sides in one model. This paper wants to argue that the factors should be separated and should also be measured separately.

\section{Applying the pyramid model to tourism destinations}

Following the above argument it is suggested to distinguish competitive position and competitive potential as a first step. The competitive position refers to the competitive performance, which is an output, and can be measured by statistical data. This shows the status of the destination based on objective measurements of what has been achieved as a result of actions already carried out in the past. This can also be called the ex post concept (Barbosa et al, 2010), or an accrual-based approach (Sziva, 2010).

Competitive potential relates to what the destination could achieve, with the appropriate development of the facilities and management activities - that is all the factors and determinants, which can influence the competitiveness of a destination. Competitive potential in other words is the ex ante concept (Barbosa et al, 2010), but others refer to it as the development oriented approach (Sziva, 2010).

The pyramid model outlined below is used in regional economics to analyse the competitiveness of both cities (Parkinson et al, 2006) and regions (Gardiner et al, 2004, Lengyel, 2004). The greatest contribution was made by Lengyel (2000, 2004, 2010), who continuously developed his pyramid model both to find a way of measuring and facilitating regional 


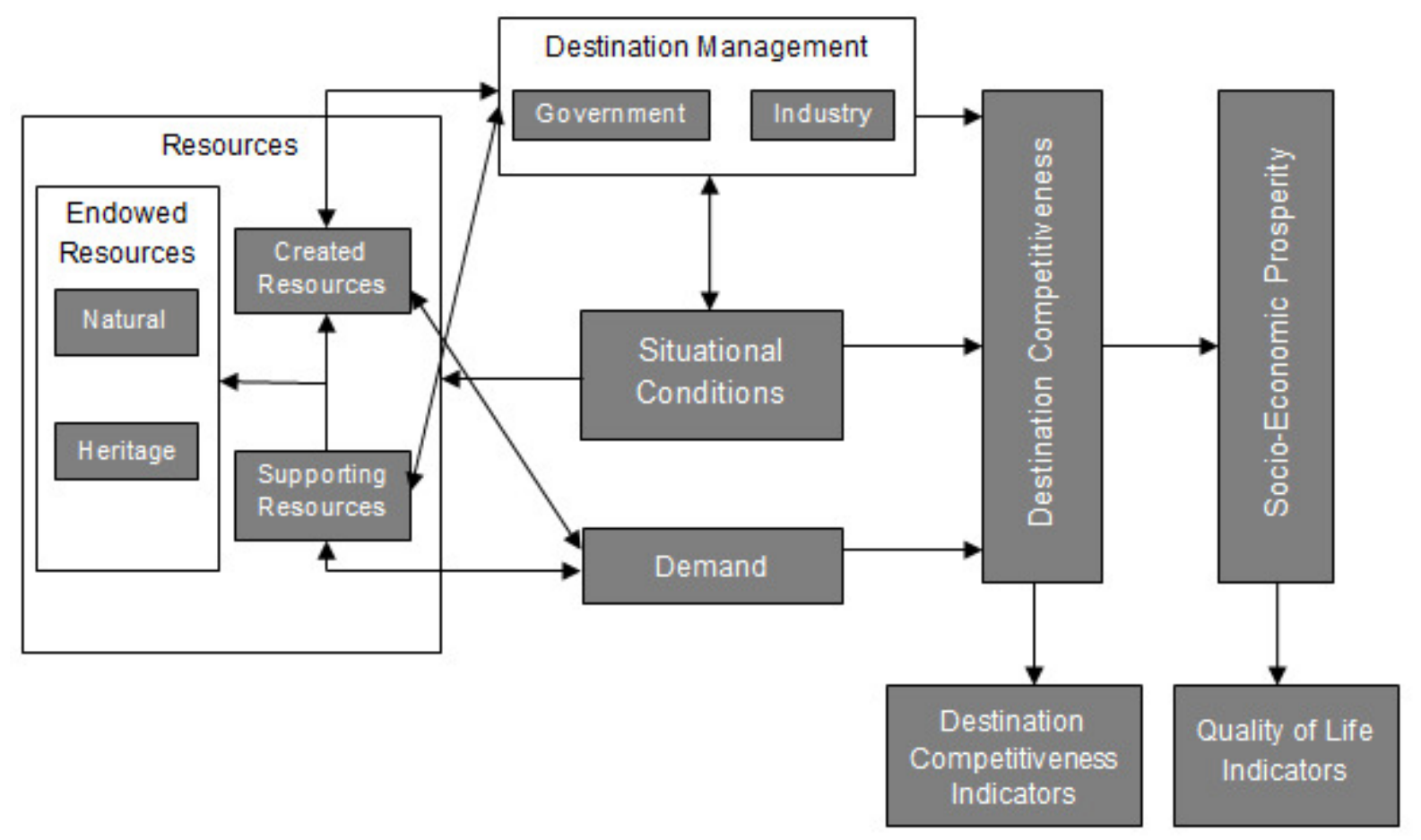

Figure 2. The Integrated Model

Source: Dwyer et al, 2004

development. This model separates the cause and effect parts, that is the competitive position from the competitive potential, as Figure 3. shows.

The competitive position appears on the third level, where the basic categories are located. These categories measure competitiveness through established variables or factors including income, labour productivity, employment and openness, that is, these are the ex post indicators (Lengyel, 2004).

In tourism, the competitive position can be measured by several tourism statistics. Furthermore, employment and productivity are also important, and the latter can be assessed by tourism income per visitor. The number of visitors, guest nights or even occupancy rates can also be of use for measuring the competitive position.

The competitive potential can be further divided into two parts in this model: success determinants are the resources, that is, social and environmental conditions in regional economics, and primarily the attractions in tourism. The determinants in this category can be changed over a longer period of time, but are very important and have indirect impacts on the basic categories.

Development factors on the other hand are the real ex ante factors that can be developed (even in the short term) and can help to make a direct impact on the basic categories (Lengyel, 2004).

The factors that influence the competitiveness of a destination, in this case of post-socialist countries as tourism destinations - are in the footings of the pyramid.

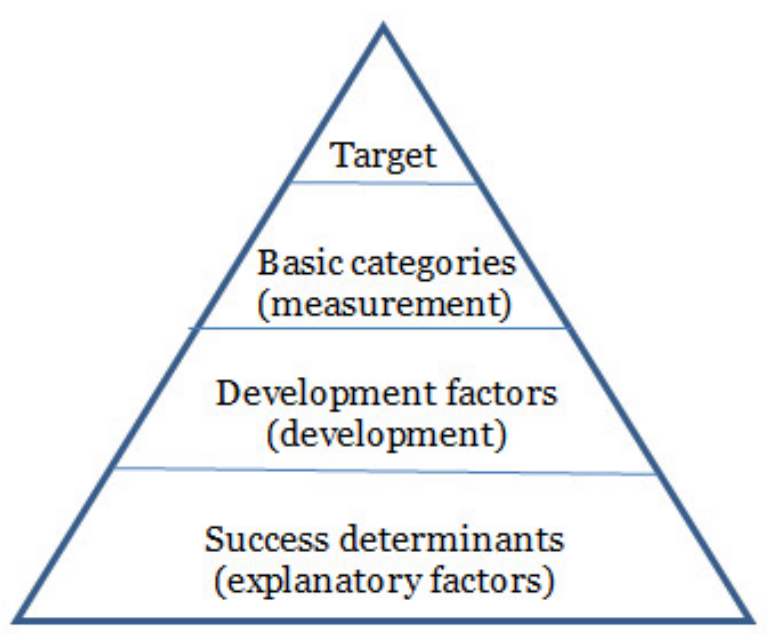

Figure 3. The Structure of the Pyramid Model Source: Lengyel, 2004, 2010

As mentioned before, the pyramid model has been developed for regional competitiveness. In this paper the adaptation is used which is tailored it to the specificities of tourism. The pyramid model of the tourism destination competitiveness is shown in Figure 4 .

The suggested pyramid showing the structure of factors of destination competitiveness combines elements from the Crouch and Ritchie and the Dwyer et al. models of destination competitiveness and the Lengyel model of regional competitiveness. The footing of the pyramid comprises the building blocks of what we see as competitive potential which are mostly static elements, demonstrating relative fixity, which although can make places attractive to tourists 
and can change or be changed only over a long period of time. The notions in the boxes below the line are still factors of competitive potential but these are elements that can be changed over relatively short periods of time as they are characterised by low levels of fixity.

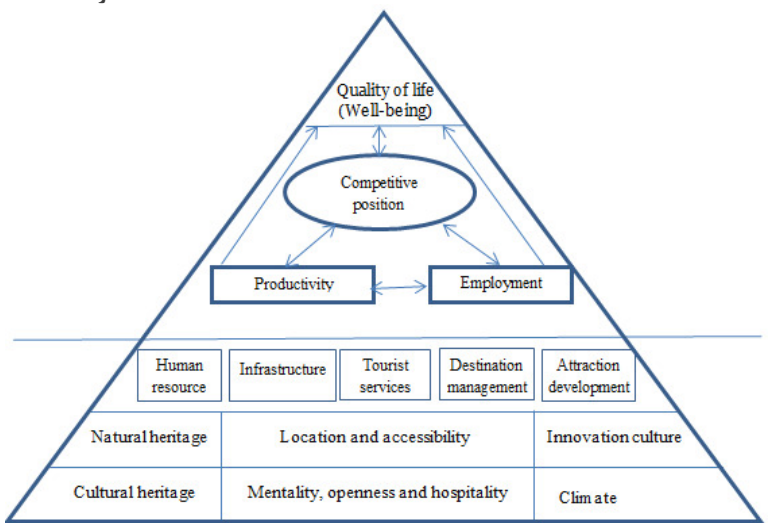

Figure 4. Pyramid Model for Tourism Destination Competitiveness

Source: own compilation

\section{The pyramid before the regime changes}

With regards to competitive position, as it has been discussed before, there was no competition to speak of in the socialist era. Although the base of the pyramid (potential part of the pyramid) was present, there was hardly any conscious development of the elements in this category. Furthermore, there was no or little connection between competitive potential and competitive position of tourism destinations (because of the reasons that we outlined earlier) that is showed on Figure 5 .

Due to the lack of real competition, competitive position was not an issue and therefore there was no need to improve the destination offer for these reasons, neither in terms of attractions nor quality of services. The boxes in the pyramid were left empty deliberately to indicate that factors such as human resources, infrastructure development, etc. played a less important role in the era of socialism due to the centralised direction of tourism flows. There was no need to make the destinations more attractive as they had the 'guaranteed' flow of tourists anyway. Activities done in these areas were undertaken to maintain the status quo or to react to other policy initiatives and not necessarily to improve attractions or facilities.

The link between the factors of competitive potential and competitive position was not recognised; in fact the whole notion of competition was not recognised as it is a capitalist notion denied by the socialist paradigm.

\section{The pyramid after changes}

Reviewing the previous arguments, the significant changes in the tourism of the post socialist era will be discussed here. Competition appeared and arose between destinations, both within the countries (as people were not restricted to certain resorts where the state provided holidays for them), and between countries, which in turn had resulted in changes in the tourism market. Due to the higher quality requirements from the tourists the standard of tourism services has also risen. The higher standards could only be achieved by the improvement of the 'potential' factors of the above outlined pyramid. The noticeable developments in the field of infrastructure have been made available by EU funds and the leverage this permitted with international investors. Attraction development started to focus on visitorfriendly services as the masses of visitors were not guaranteed any longer, the attractions had to compete for tourists. In the area of human infrastructure the noticeable changes were the introduction of tourism and hospitality courses and the rising need for speaking foreign languages. In Hungary for example, German used to be the language of communication with tourists as the majority of them arrived from the German speaking countries (KSH, 1999), but with tourists coming from a wider range of countries English has slowly started to become the language of communication with visitors. These few examples show that the factors influencing competitive potential have started to gain importance and the link between the potential factors and the competitiveness of a destination has started to be recognised. The following part of the paper will provide examples for the changing importance of some of the potential factors from the bottom of the pyramid.

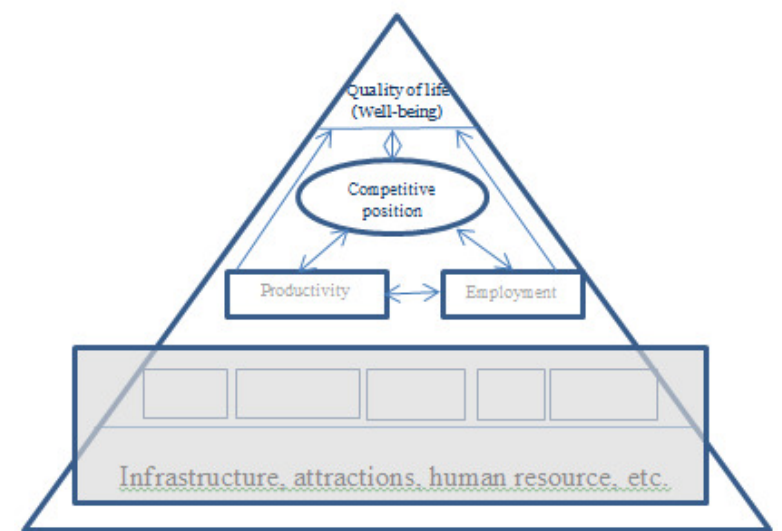

Figure 5. Pyramid Model of Socialist Era (not country specific)

Source: own compilation 


\section{Infrastructure: Accessibility}

With the introduction of low-cost airlines the former socialist countries have become more easily accessible within Europe. Most flights started to operate around the time of EU accession. This can be explained on the one hand with governments entering the Open Sky European Airspace Agreement usually at the same time or around the time of joining the EU. Before the Open Sky agreement, governments were able to impose restrictive legislation to protect their national carrier from competition. With the arrival of the low-cost airlines the options have widened and fares have become affordable to many more potential tourists. From 2004 onwards, when 10 new members joined the EU at the same time, existing (Western Europe-based) low-cost carriers such as easyJet and Germanwings started operating new routes to the former socialist countries, and new no frills airlines were established based in these countries like SkyEurope, which has stopped operating due to the economic crisis, and the Polish-Hungarian joint venture WizzAir, which started on the $19^{\text {th }}$ of May 2004 from Katowice. On the other hand the revival of interest in countries of the former Soviet block also helped to put them back onto the tourist map of Europe. However, it has to be noted that the ease of access made these countries more appealing to Western Europe anyway, partly because the cheap flights made these countries ideal destinations for short breaks and partly because people started to buy second homes or holiday homes in the region.

Access to destinations was also improved by the development of regional airports. Some of the airports had originally been used for military purposes, and were gradually turned into civil aviation airports by the time of the regime change.
Their development was accelerated after the EU accession (Fas, 2003). These regional airports, differing in size and importance, emerged as competitors for smaller established hub airports, so we see Krakow and Katowice airports in Southern Poland emerging to become competitors for Prague (Tloczynski, without date). The smaller regional airports have quickly become popular with low-cost airlines as they offered services at significantly lower prices than the larger hub airports, especially the ones in capital cities. Although the economic recession starting in the autumn of 2008 has impacted on air travel and low cost airlines in particular, some of the regional airports near popular destinations are still being developed, such as at Varna airport where the reconstruction of the runway will take place in the winter of 2011/12 (varnaairport.bg).

\section{Tourism infrastructure: Accommodation}

Due to recession and lack of resources after the economic restructuring the state could no longer afford to run the hotels and other types of accommodation formerly used for domestic tourist not to mention investing in their refurbishing or development, these have also become subject to privatisation in the early 1990s. Privatisation has brought in some foreign investment, accommodation in popular resorts and destinations were purchased by larger hotel chains. Some of the hotels were purchased through management buy-out or even by the employees (Light and Dumbraveanu, 1999). On the one hand, this type of change of ownership was welcome as continuation could be ensured this way (people who had significant knowledge and experience about running the hotel remained in

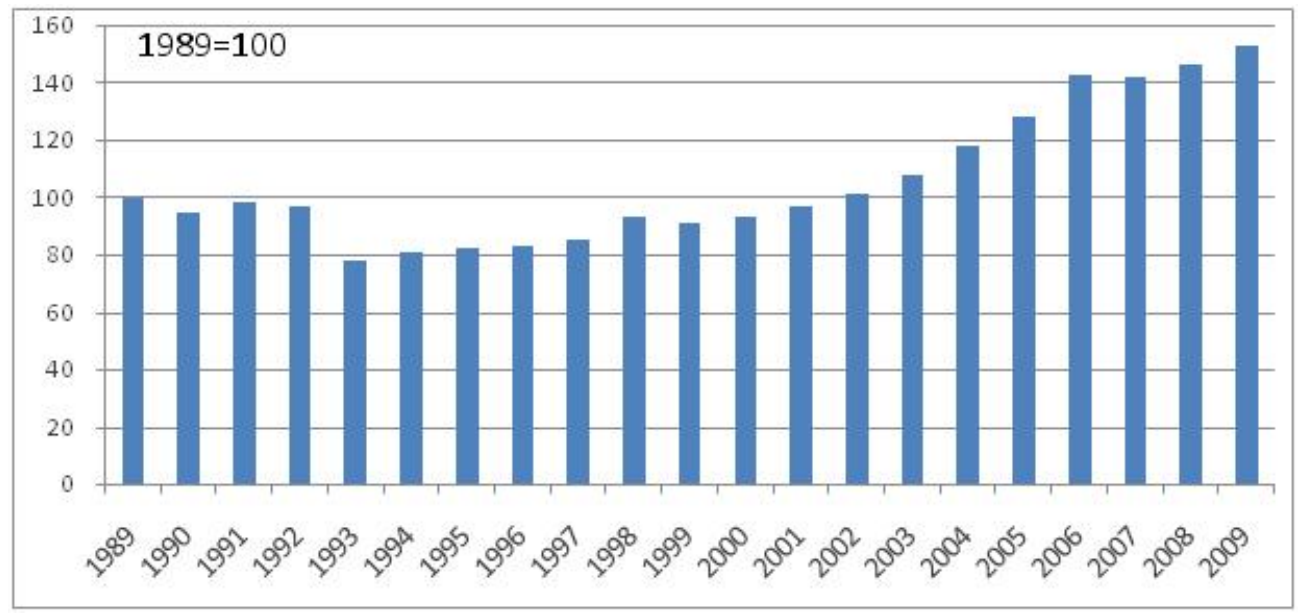

Figure 6. Changes of Accommodation Capacity in Romania Source: Comisia Nationala pentru Statistica, 2010 
place). On the other hand, the employees and even the management did not have sufficient funds to invest in the hotels to ensure high enough standards that would suit Western tourists.

The number of accommodation units as well as overall capacity fell in the first half of the 1990s; especially the number and capacity of the lower standard establishments that used to cater for domestic tourism with lower acceptable standards. Only hotel capacity has remained the same or has grown slightly, in particular in hotels offering higher standards, such as hotels with three stars and above (Comisia Nationala pentru Statistica, 1998, KSH 1999). In the case of Romania for example, from the middle of the decade the number of accommodation units started to rise again but it had taken more than ten years to reach the number recorded in 1989.

From 2000 onwards the approaching EU accession has accelerated accommodation development in some of the former socialist countries. Ten years after the changes the economies have stabilised to some extent and the countries have become eligible for PHARE funds to improve their tourism infrastructure. The anticipated demand for more accommodation capacity as a result of joining the EU has also contributed to the relatively slow but constant growth in bed capacity between 2000 and 2006 in Romania, Bulgaria and Hungary while Poland experienced a slight decline in the number of accommodation establishments (EuroStat, 2008).

Besides the growth in capacity the change in quality of accommodation has also been noticeable. The use of the term change was deliberate as the period after the regime change experienced both decline and improvement in terms of quality in the countries in question. In the first few years of the transition period the quality of accommodation in general declined as the new owners usually had just about enough financial resources to buy the property but not enough for maintenance or improvement. However, to be able to compete in a more demanding environment the refurbishment could not be put off for too long otherwise the accommodation units lost their business.

The introduction of standards for tourist accommodation has also resulted in quality improvement. Legislation to ensure standards acceptable for a more demanding audience was passed, with detailed description of the necessary requirements for the different types of accommodation (Monitorul Oficial, 1998). However, standards were not equally enforced in the countries analysed. Ion-Tudor (1997) for example reports on tourism facilities at the coastal resort of Mamaia in Romania where only about $12 \%$ of all the units held a licence in 1997.

\section{Attractions: reinterpreted past}

The regime change has brought along changes in cultural identities as well. The societies of the former socialist countries have had to face difficult decisions in the suddenly gained freedom. The first reaction was to get rid of everything that reminded people of the past but with the anger passing people started to see the old features and old symbols in a new light. After some years they have become able to decide what to keep from the old system, and also how to show tourists where they are coming from (Czepczynski, 2010). As a first step of reconciling with the past, societies have started to realise the potential in re-using some of the features of the old system. Icons and symbols of the socialist/communist era have become tourist attractions (such as the Lenin Monument in Bucharest, moved from the House of Free Press to a suburb, featuring in the Rough Guide to Bucharest (Richardson and Burford, 1995). Several of the former socialist countries re-positioned some of these icons, such as statues of Lenin and Stalin. One of the best examples is the Statue Park in Budapest, visited by thousands of tourists every year, another one can be found in Kozlówka in Eastern Poland (muzeumzamoyskich.pl).

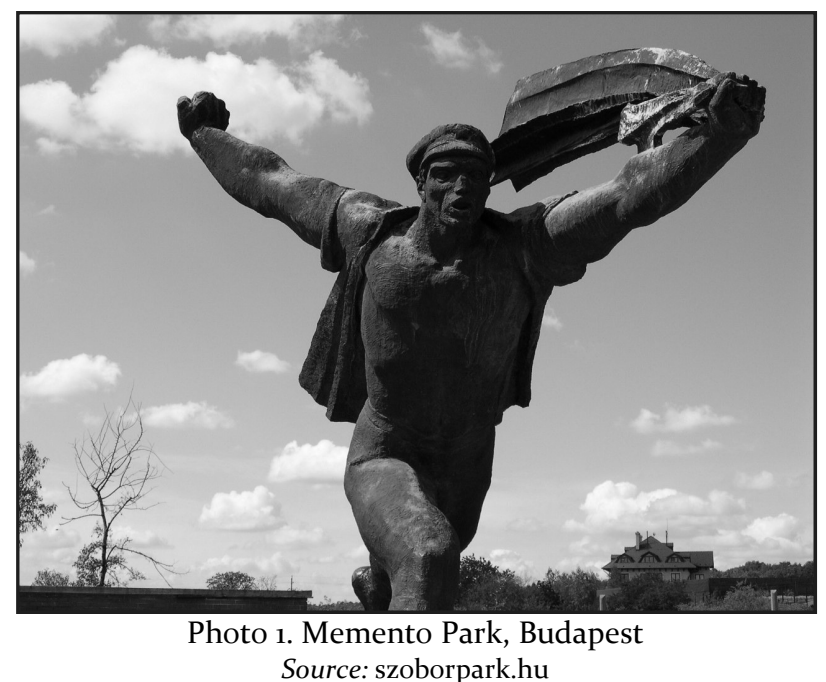

Bucharest has also got a similar dedicated space for the collection of many forms of socialist icons, in the Park of Totalitarianism and Socialist Realism. It must be noted however that the re-interpretation of socialist or communist icons was also seen as a solution to turn a destination with limited local attractions into a competitive place, meeting growing tourist demand.

Another way of using the old socialist or communist symbols was manifested in the creation of themed pubs, bars or even hotels. Some examples from Poland include the Committee in Lublin, the People's Republic of Poland in Wroclaw. The interior 
design features communist propaganda, with pictures of great socialist/ communist figures such as Lenin or Marx.

Towards the end of the second decade after the changes a certain sense of nostalgia towards some of the old values has also emerged. People looking back on the bright side of the 'life before' have created the new fashion of retro products, including tourism products and services. The retro movement can be observed in various parts of the tourism industry, such as accommodation development and redevelopment, transport services and package tours just to name the most popular ones.

All four countries in question have experienced the revival of styles in accommodation design that were characteristic of the socialist times. Some examples of hotels (re)furbished according to pre 1989 style even carry the term retro in their name, such as the Club Aliga Retro Resort in Hungary (www.clubaliga.hu), the Willa Olimp Retro in Poland(olimp-rzemieslnik.pl). These retro hotels attract both people who remember the socialist era and wish to bring back memories of the time as well as younger generations who cannot remember life in the socialist times but have a natural feeling of curiosity what it might have been like in their parents' or grandparents' time.

The retro idea has also penetrated into transport services. Larger cities with tramlines have introduced retro tram rides; in Bulgaria retro train tourism has taken off in the last few years. Also, a combination of tourism services have been re-labelled as retro packages or retro products such as retro skiing in Bulgaria for example offered by the St. Ivan Rilski Hotel Spa and Apartments.

We would also note that the counties have addressed the issues directly in creating marketing strategies for tourism to capture this new sense of marketisation. As examples we would attention to Petreas (2006) on Bulgaria and Nedelea (2004) on Romania. We would also note that the changes are still working through as the new marketing campaigns for Romania demonstrate (Romania Insider, 2011).

\section{Conclusion}

One of the consequences of the regime changes has been the introduction of a capitalist logic of competition into all aspects of these societies. Where previously tourism had been centrally planned and directed leaving managers to deal with their allocated numbers of arrivals, the new managers have to go and find the tourists within the competitive markets. This has impacted directly and indirectly on the provision and support of tourism in these former socialist countries. As a response to these changes. tourism managers have had to learn to recognise and appreciate the factors involved in competition both within the countries and in the wider international markets that they are involved in.

This led us to consider the need for an explanatory model which we drew from experience in regional economics and largely western based tourism. The pyramid model presented here does not only identify the competitive position of tourism but also the capacity for potential development of that tourism. We believe therefore that the pyramid is not only an analytical model but also a diagnostic aid to encourage tourism managers to address the challenges they are facing more successfully.

The evidence from these countries shows that the provision of tourism is being repositioned and redefined, using elements of the old to find a competitive position within the new. Our analysis suggests that it is possible to reinterpret and reposition without losing the distinctiveness of the past but reframing it as an attraction for the future tourist. Much will depend on how the tourism managers address the combination of old and new interpretations as they seek to maintain, renew and enrich the tourism offers in these former socialist countries.

\section{Bibliography}

Armenski, T, Gomezelj, DO, Djurdjev, B, Deri, L \& Aleksandra, D 2011, 'Destination Competitiveness: A Challenging Process for Serbia', Journal of Studies in Human Geography, vol. 5. no. 1. p. 19-33.

Baleanu, V, Irimie, S \& Ionica, A 2006, About the Romanian Tourism Potential: The Natural Strength of the Main Tourism Destinations online at http://mpra.ub.unimuenchen.de/9587

Barbosa, LGM, de Oliveira, CTF \& Rezende, C 2010, 'Competitiveness of Tourist Destinations: The Study of 65 Key Destinations for the Development of regional Tourism', Revista de AdministraçăoPúblicia, vol. 44. no. 5 . p. 1067-1095.

Blanke, J \& Chiesa, T (ed.) 2009, The Travel and Tourism Competitiveness Report, World Economic Forum, Geneva

Clarke, A 2010, 'Best in Show: Central Europe and Tourism Competitiveness' in A Clarke (ed.), Tourism Competitiveness, University of Pannonia Press, Veszprém, 11-22.

Cracolici, MF \& Nijkamp, P 2008, 'The Attractiveness and Competitiveness of TouristDestination: A study of Southern Italian Regions', Tourism Management, vol. 30, p.336-344.

Croes, R 2011, 'Measuring and Explaining Competitiveness in the Context of Small Island Destinations', Journal of Travel Research, vol. 50, no. 4, p. 431-442. 
Crouch, GI 2011, 'Destination Competitiveness: An Analysis of Determinant Attributes', Journal of Travel Research, vol. 5o. no. 1. p. 27-45.

Czepczynski, M 2010, 'Interpreting post-socialist icons: From pride and hate towards disappearance and/or assimilation', Human Geographies- Journal of Studies and Research in Human Geography, vol.4. no. 1. p.67-78.

Dwyer, L \& Kim, C 2003, 'Destination Competitiveness: Determinants and Indicators', Current Issues in Tourism, vol. 6, nr. 5, p. 369-414.

Dwyer, L, Forsyth, P \& Dwyer W 2011, Tourism Economics and Policy, Channel View Publications, Bristol

Dwyer, L, Mellor, R, Livaic, Z, Edwards, D, \& Kim, C 2004, 'Attributes of destination competitiveness: a factor analysis', Tourism Analysis, vol. 9. p. 91-101.

EuroStat Tourism Statistics European Commission, 2008

Fas, MA 2003, CA2003C - Airport Business Management : Polish Airport Market Analysis, Semester Paper, Metropolitan University, London, available at slideshare.net

Gardiner B, Martin, R \& Tyler, P 2004, 'Competitiveness, Productivity and Economic Growth across the European Regions', Regional Studies, vol. 38. no. 9. p. 1045-1067.

Gomezelj, DO \& Mihalic, T 2008, 'Destination Competitiveness - Applying Different Models, the Case of Slovenia', Tourism Management, vol. 29, no. 1, p. 294-307.

Hall, D 1991, 'Evolutionary Pattern of Tourism Development in Eastern Europe and the Soviet Union' in D Hall, (ed.) Tourism and Economic Development in Eastern Europe and the Soviet Union, Belhaven, London, p. 79-115.

Ion-Tudor, C 1997, 'Who is Controlling Tourism in Seaside and Spa Resort', Romania Business Journal vol. 4 no. 26. p. 16.

Jancsik, A \& Mayer, P 2010, 'The Network Aspects of Tourism Competitiveness' in A Clarke (ed.), Tourism Competitiveness, University of Pannonia Press, Veszprém, 191-209.

Központi Statisztikai Hivatal (KSH) 1990-2011. www.ksh.hu Lengyel, I 2004, 'The Pyramid Model: Enhancing regional
Competitiveness in Hungary', Acta Oeconomica, vol. 54., no. 3., p. 323-342.

Lengyel, I. (2000): “A regionálisversenyképességről” KözgazdaságiSzemle, vol. 47. p. 962-987.

Lengyel, I. (2010): Regionális gazdaságfejlesztés, Akadémiai Kiadó, Budapest.

Light, D \& Dumbrăveanu, D 1999, 'Romanian Tourism in the Post-Communist Period', Annals of Tourism Research, vol. 26. no. 4. p. 898-927.

Nedelea, A 2004, Marketing Strategies of Tourism in Romania Economic Review of Tourism, Vol. 3, available at SSRN: http://ssrn.com/abstract=1269369.

Parkinson, M et al. 2006, State of the English Cities, A Research Study, Volume 1, Office of the Deputy Prime Minister, London.

Porter, M 1990, The competitive advantage of nations, The Free Press, New York

Richardson, D \& Burford, T 1995, Romania: The Rough Guide ( ${ }^{\text {st }}$ ed.), Rough Guides Ltd, London.

Ritchie, JRB \& Crouch, GI 2003, The Competitive Destination: a Sustainable Tourism Perspective, CABI

Romania Insider 2011, Romania's tourism marketing programs revealed: 'Guardian Angels', 'We Care', 'Romania Welcomes You', viewed February 17, 2011, http://www.romania-insider.com/romanias-tourismmarketing-programs-guardian-angels-we-care-romaniawelcomes-you/19086/\#

Sziva, I 2010, 'A turisztikai desztinációk versenyképessége. Egyedül miért nem, együtt mikor és meddig?', Turizmus Bulletin, vol. 16. no. 3. p. 40-49.

Tloczynski, D (without date), Marketing Strategies of Polish Airports: Towards European Union, available at www.konferencja.edu.pl/ref8/pdf/en/TloczynskiGdansk.pdf.

Vanhove, N 2010, The Economics of Tourism Destinations, Elsevier, Amsterdam

Wingrove, D 1997, 'Tourism in Romania: An Offer you CAN'T Resist?', Review Romania, vol. 18. (July/August) p. 4-5. 